\title{
An Alternative Approach to Building Construction: Natural Building Techniques
}

\author{
Yasemin Erbil ${ }^{1}$
}

\begin{abstract}
:
Concerns about the environment around the world are increasing in recent years. As a countermeasure to these concerns, interest in natural building techniques has begun to increase because of the high environmental, social and economic costs of existing construction methods and the potential for natural structures to be a solution to the problem of sustainable living. With natural building techniques it is possible to construct buildings with materials and techniques that are ecologically sound, culturally sensitive, based on local resources and skills, and affordable to local residents. Adobe buildings, cob buildings, earthbags, rammed earth buildings, straw bale buildings, earthships are among the construction techniques utilized for this purpose. In this article, natural building techniques are introduced in a general framework. Increasing usage of natural construction techniques that have the potential to be a solution to the environmental problems in the world by the construction professionals and the construction sector, and supporting developments with research, supporting volunteers, who will take steps in this field, with government policies, and increasing the interest of the users and their awareness should be regarded as a necessity.
\end{abstract}

Keywords: natural buildings, earth buildings, straw bale buildings, earthships

\section{Introduction}

Today there is a reaction to the negative impact of construction methods on the environment. In recent years, people from various parts of the world have come together to bring societies to life, and through social co -operation, they move towards building materials and techniques that are ecologically sound, culturally sensitive, based on local resources and skills, and affordable to local residents. The common features of these structures are the construction of the building with materials in located in the land itself or its immediate surroundings; a design that uses sunlight in winters, protection from sunlight in summers; the use of local and non-toxic materials; the minimization of the process; the avoidance of damage to nature; support of local businesses and human resources; and construction with an appropriate size. At this point it is useful to note that although traditional construction techniques and natural construction techniques are very similar to each other, they are two essentially separate systems at the core. In traditional construction, the construction materials that are produced (manufactured) are mostly standardized materials. In the case of natural construction, the materials used are provided immediately or from a very close range. Purchase is limited, and the materials that are used are mostly those reserved for recycling. With natural building techniques it is possible to build buildings with materials and techniques that are ecologically sound, culturally sensitive, based on local resources and skills, and affordable to local residents. 
Some of the techniques utilized for this purpose are adobe brick buildings, cob buildings, rammed earth buildings, earthbag buildings, straw bale buildings, earthships.

\section{Earth buildings}

Since ancient times and in every part of the world, earth is the most common material that people use to build their houses. Despite all the developments in technology, in the twenty-first century, a very large part of the world's population lives in soil structures. In today's stage of civilization, soil constructions provide shelter for to low-income population groups but also to high-income groups who prefer to live in a healthy and comfortable environment. interest in soil constructions increase as concepts such as environmental protection, energy saving and sustainability gain importance and as the problems in this area grow (Kafesçioğlu, 2017).

The soil structures can be examined in four groups according to the construction system (Minke, 2006): (1) adobe brick buildings, (2) cob buildings, (3) rammed earth buildings, (4) earthbag buildings.

Adobe Brick Buildings: Adobe is the oldest building material used by mankind (Hunter and Kiffmeyer, 2004). In addition to being a local material, it is an environmentally sensitive and ecological material that consumes the least amount of energy for its production and use, and provides favorable conditions for human health. The main ingredient of adobe is soil. Sand and pebbles in the soil work as the framework and clay works as the binding agent (Kafesçioğlu et al. 1980). Adobe brick blocks are made by mixing clay loam, straw, vegetable fibers, diluting this mixture with water and then pouring them into molds and drying them. In structures they are used in two ways: (1) Masonry constructing using adobe bricks. (2) Supporting adobe bricks with wooden frames. The strength is determined by the ratio of materials used in the production of adobe bricks. There are regional differences in adobe bricks because adobe itself is a local material. Mud with suitable consistency for adobe brick production is usually shaped by pouring it into wooden molds and them by letting them to dry. To be able to use adobe bricks, they need to be completely dried (Hunter and Kiffmeyer, 2004). Adobe is also used as an adhesive mortar when the bricks are combined. Adobe has considerable advantages over other materials in achieving habitable comfort conditions in interiors (Cassell, 1993). Adobe bricks and blocks can take the place of concrete blocks in many interior applications; but they are not suitable for outdoor use in some climates, as they have little resistance to moisture and water (Morton, 2007).

Cob Buildings: Cob Buildings are one of the traditional techniques using earth. A mixture of clay soil, sand, straw and water is used. These buildings are constructed by stacking adobe on a stone foundation to form a single wall (Hamard et al., 2016). Its application is easy. This process can easily be done manually (Houben and Guillaud, 1994). When the resulting mud is still moist, it is piled up in piece by piece. For the stability of the wall, it is necessary to wait for each layer to dry before forming the next layer. Cob Buildings are similar to adobe brick structures. The ratio of straw, which holds the mud together is higher than the ratio of adobe bricks (Niroumand et al., 2013). Advantages of using Cob 
Building construction techniques include: ability to provide the material from the construction site, constructing creative solutions that enable the placement of various furniture, shelves, etc. within wall sections, ease of understanding and implementing, and the ability to reshape when needed and to socialization (Bee, 1997).

Rammed Earth Buildings: Rammed Earth Buildings is one of the traditional construction techniques used since past. The forged wall is formed by pressing adobe between molds to obtain a monolithic wall. It is known that a part of the Great Wall is made by this method (Niroumand et al., 2013). In conventional methods, the mud is transferred into the molds and pressed by hand force. Today, pressurized mechanical compressors are used for compression (Hunter and Kiffmeyer, 2004). After the soil is dry enough, molds are removed and fine workmanship is carried out. Wall thickness is between $30-60 \mathrm{~cm}$ in general. The strength of the wall depends on compaction of the soil and preparation of the mixture. Forged walls must be sufficiently moist during production to allow the soil to stand together (Hall and Djerbib, 2004). Today, mudbrick forged walls are produced prefabricated. Especially in England, the wall thickness decreases to $10-20 \mathrm{~cm}$ (Walker et al., 2005). Rammed Earth Buildings can also be used in moist and rainy areas such as North Africa and Australia where the use of adobe bricks is not possible (Niroumand et al., 2013). Compared to adobe brick construction, it is an easier and quicker system because it does not require two separate processes for brick production and wall construction. The shape and design of the walls made with rammed earth are limited, because removable molds are needed in their preparation. However, after the molds are dismantled, the design can be enriched by fine workmanship on the wall.

Earthbag Buildings: This construction technique, which can be easily applied wherever the material can be procured, is one of the sustainable, fast and low cost alternatives of construction with soil. The origin of this technique dates back to military shelters and was first applied by the Iranian architect Nader Khalili (Sargentis et al., 2009). The Earthbag Buildings are created by filling bags with soil and creating living spaces by stacking them on top of each other. Soil is mixed with water to compress it well before it is poured into bags. Walls are created by arranging the bags in rows, side by side and on top of each other in an irregular order. After the structure is completed, earth plaster is applied on the surface in order to protect it from external conditions and to increase the strength. The ability to change the dimensions of the bags and the flexibility to shape the bags makes different designs possible. In addition to the walls, soil filled bags can be used to create the top cover of the spaces created (Zhao et al., 2015). The top cover system is usually domed or curved. Earthbag buildings can provide shelter to people rapidly in the event of a crisis, such as wars, natural disasters, and emergency situations. For example, this technique is used extensively in emergencies in Africa and South America (Canadell et al., 2016). Plasticity, simplicity of application, robustness and the possibility for flexible design are among the advantages of this technique (Sargentis et al., 2009) 


\section{Straw-Bale Buildings}

The straw-bale construction technique is a technique that has been used for centuries in the world; it is healthy, low cost, easy to rapidly implement by everyone, and requires less workmanship and much less mastery compared to other construction techniques. Straw-bale buildings have many advantages. These advantages are savings in the embodied energy, sustainability of straw as a building material, and the improved thermal performance of the building (Magwood, 2005). Since the thermal conductivity resistances of the bales are very high, straw bale walls do not require any additional insulation material. Straw-Bale Buildings provide savings in the initial investment and upkeep because they do not need additional insulation materials and they reduce the fuel consumption required for heating and cooling. The construction of a straw building supports personal creativity and allows many people to participate in the process of producing their own living space. Constructing a building with straw requires less workmanship and much less skills than building with concrete, brick, mudbrick or stone. Some of the other factors that reduce the costs are the ability to procure building materials at low prices, and the ability to carry out the construction by anyone (Eryildiz and Başkaya, 2000).

Buildings constructed with the Straw-Bale technique have shown extraordinary results such as high fire and earthquake resistance, very high heat and sound insulation that is almost ten times more than wood and bricks, high energy efficiency, and minimum maintenance requirements (Gowini, 2002). There are some common properties that must be considered when constructing any structure with the Straw-Bale technique. These are voids, pinning, water protection, details, and precompression (King, 2006). With proper moisture control, a straw bale structure can last as long as any conventional wood framed house (Garas et al., 2009). Although it has various disadvantages, building professionals agree that straw can be an excellent construction material and recognize that some of these disadvantages can easily be solved (Ashour et al., 2011).

Based on their structure resistance, Straw-Bale constructions are divided into three categories: construction with load bearing straw bale structure, straw bale construction with timber frame structure, straw bale construction with prefabricated walls (Adedeji and Bello, 2011).

Nebraska-style building, which is construction with load bearing straw bale structure, is the original way of building with bales of wheat straw. This style is preferred by most builders because of its simplicity, flexibility and easy design, but mostly for thermal efficiencies and minimal price. With this method, straw bales serve as building blocks that are ready to support the weight of the roof with no need for additional structures. Bales are positioned as masonry blocks, caught base pin (wooden stakes fix size) and each pin drop as wood. In buildings that have a ground floor and a first floor a wooden base is positioned all around the walls so that it can be fixed and intermediate floor. It is possible to arrange windows and doors in various ways. A simple method is to place a wooden frame in the building's wall structure. This method is useful in the construction of small buildings. Because it is very accessible but use more wood and keep the simple look of construction (Hodge, 2006). 
Many Nebraska structures built with bale walls are usually square or rectangular. The advantages of this system can be summarized with ease of design and construction, and the savings in money, time, materials and labor. But the disadvantages of this system are the constraints of design (the impossibility of using a very heavy roof), the necessity of flat and dense bales, and the necessity of waiting without plastering so that the walls can acclimatize to the roof top. In the carrier bail technique, when there is no clearance (window, door, etc.), the bale wall strength and stability is not questioned. The top windows do not affect the strength of the building, but it is not wise to place all the openings in one wall. Another issue is the distance between the openings and the distance of an opening to the corner. This should not be less than one and a half bale size on both sides. Wide openings require a sturdy lenticular or a rigid roof structure to receive the roof load above the openness. For this reason, the openings should be designed narrow and high, not broad and low (Myhrman and MacDonald, 1997). The solution of using load-bearing straw bale walls is a simple, uncomplicated, and easy to use method even for untrained people, who only need to follow basic principles of this technique. A disadvantage of the load-bearing technique is the necessity to keep the straw dry during the whole building process. Pre-fabrication of building components minimizes the time of exposure to the weather, and the need to keep the straw waterproofed can be reduced to a few weeks. Floors and roof themselves act as the main weather protection (Jones, B. 2009) (Hollis, 2005).

Straw-Bale construction using timber frame structures is another traditional method. With this method the weight of the roof is taken by a wooden frame. Straw bales are basically just filler with no charge. This technology requires an adequate design of the building, correlated with the size of the bale to be used. Even if plans are made by classic construction, the bales can easily be resized to according to the size of the building. The most difficult part is preparing bales for plastering, which is a process that requires high attention. Long wires protruding straw bales are cut to create a uniform wall. In case of straw bale construction with timber frame structure, it is important to have well compressed bundles to avoid heat loss. It is preferable to use well pressed bales but is recommended to further compress the walls before applying the plaster on the wall.

A prefabricated straw bale wall is a solution that has various benefits such as perfectly straight walls, no need for special work, vertical spaces that are filled perfectly with straw unlike other methods described above, no possibility to have gaps after pressing the bale, no need to resize bales for wall ends, and easy handling of the wall (Cantor, 2015).

\section{Eartships}

Earthships aim to show that there are alternative ways of living against the environmental problems of the world. These are houses, which are independent from all centralized infrastructure networks, which are self-sustaining and are 100\% sustainable, and made from recycled materials produced by the American architect Michael Reynolds, produced with renewable and sustainable energy, and an approach that emphasizes returning back to the nature. They are made from materials that people regard as garbage, such as used tires, aluminum beverage cans and glass bottles. Michael Reynolds 
also has a documentary entitled "Garbage Warrior", which is about the fight against state authorities to create these houses.

Earthship has six basic design principles: collection of rainwater, energy production with renewable sources such as solar and wind power, sewage treatment, thermal / solar heating and cooling, food production, construction with natural and recycled materials. Earthships make new types of structures possible in the outer parts of the city, where the infrastructure system does not exist or cannot be built, because it does not need to be connected to any infrastructure system. In addition, costs are little enough to be ignored. Tires, which are burned and create large amounts of toxic gas, are used in Earthships and create the thermal mass. Used tires are filled with soil, and the soil is then compacted to $90 \%$, which creates a 150-kilogram brick. The main walls of these houses are built using these bricks. Because these walls are not rigid like concrete and they are made of a flexible material such as tire rubber, they gain resistance to the stress of earthquakes and have greater fire resistances as they are compressed with the soil.

Another recycled building material used in Earthships is glass bottles and aluminum boxes. These materials are used as 'small bricks' to form non-structural interior partition walls. The placement of these objects in walls is intended to create a volume in walls and to prevent the use of redundant building materials, and to provide insulation. (Reynolds, 1990)

In general, three façades of Earthships' are made with heavy walls, and the south sides are designed to be facing the sun to benefit from maximum sunlight. Also tires filled with soil act as thermal mass for heating and cooling needs in Earthships. Therefore, even in hard desert climates, where the temperature reaches $45^{\circ} \mathrm{C}$ in summers and -30 ${ }^{\circ} \mathrm{C}$ in winters, the temperature can be kept constant at comfortable room temperature without the need for any other system.

These natural homes also have a natural ventilation for air intake and exhaust. Beneath the ground, cool air coming from the air pipes is pulled out and the air is taken out from the air exhausts above. Thus, a natural air circulation is created in the house. In addition, greenhouses in the house provide clean air.

In Earthships, gray water from bathtubs and sinks is purified in the botanical cells that plants are grown. This water is then reused as siphon water, so that the same water is used three times, which creates significant water savings. Black water that emerges after the siphon is used, is dissolved in a septic tank buried outside and act as a kind of liquid fertilizer in outdoor botanical cells so that it does not need to be connected to the sewer line. The water stored in the water tanks during such periods of abundant rainfall meets the water requirement of the house for a period of four or five months without rainfall. Earthships use solar panels and wind turbines to generate electricity. The power produced is stored in batteries. Wind turbines are added to the system in places where the sunlight is not sufficient for electricity. Therefore, such structures are not dependent on any power network. (Reynolds, 2000)

\section{Conclusions}

Today, there is an increase in demand for sustainable living, but traditional knowledge has disappeared in areas that have a developed industry. Therefore, as a 
necessity for a sustainable life, natural construction techniques, which have the potential to be a solution to the environmental problems in the world, should to be adopted by construction professionals and construction sector, developed through research, volunteers, who would like to take steps in this field, should to be supported with state policies, and users' awareness level should be increased. At this point, it is important to regard natural construction techniques as a solution of our era, rather than the last resort before our resources are consumed.

\section{References}

Adedej1, A. A., Bello, J. A., (2011). Construction Procedure of a Straw Bale Walled Building - a review. Annals of Faculty Engineering Hunedoara - International Journal of Engineering, IX (3):255-262

Ashour, T., Georg, H., Wu, W., (2011). Performance of Straw Bale Wall: A Case of Study. Energy and Buildings, 43:1960-1967

Bee, B. (1997). The Cob Builders Handbook: You can hand-sculpt your own home.

Canadell, S., Blanco, A., Cavalaro, S. H. (2016). Comprehensive design method for earthbag and superadobe structures. Materials \& Design, 96, 270-282.

Cantor, D. M., Manea, D. L., (2015). Using Wheat Straw in Construction, ProEnvironment 8:17-23

Cassell, R. O. (1993). A traditional research paper: Rammed Earth Construction, The compaction of successive layers of earth between forms to build a wall. Retrieved August 12, 2007.

Garas, G., Allam, M., Dessuky, El R., (2009). Straw Bale Construction as an Economic Environmental Building Alternative- A Case Study. ARPN Journal of Engineering and Applied Sciences, 4(9):5459

Gowını, El M., (2002). Background About Rice Straw Problem in Egypt: (Is rice Straw Really Waste?) by Copyright Community Times, Cairo, Egypt. October, pp.1-2

Hall, M., Djerbib, Y. (2004). Rammed earth sample production: context, recommendations and consistency. Construction and Building Materials, 18(4), 281-286.

Hamard, E., Cazacliu, B., Razakamanantsoa, A., \& Morel, J. C. (2016). Cob, a vernacular earth construction process in the context of modern sustainable building. Building and Environment.

Hodge, B., (2006). Building Your Straw Bale Home: from Foundation to the Roof, CSIRO Publishing, Australia, 49-78

Hollis, M., (2005). Practical Straw Bale Building. CSIRO Publishing: Victoria, pp.11-13

Houben, H., Guillard, H. (1994). Earth Construction, A Comprehensive Guide, Intermediate Techology Publications, London.

Hunter, K., Kiffmeyer, D. (2004). Earthbag building: the tools, tricks and techniques. New society publishers.

Irklı-Eryıldız, D., Başkaya, A., (2000). Building With Straw-bales: Construction of a Prototype in KırıkkaleHasandede. J. Fac.Eng.ARch. Gazi Univ, 15(2):87-104

Jones, B., (2009). Building with Straw Bales: A Practical Guide for the UK and Ireland, 2, Green Books, Totnes, pp.67-68

Kafesçioğlu, R., Toydemir, N., Gürdal., E., Özüer, B. (1980). Stabilization with Adobe Plaster as Building Material, TÜBİTAK, MAG-505, No:87, İstanbul.

Kafesçioğlu, R., (2017). Contemporary Construction Material Earth and Alker (Intelligent Adobe), İTÜ Publishing, İstanbul.

King, B., (2006). Design of Straw Bale Buildings, Green Building Press, pp.1-5

Magwood, C., Mack, P., Therrien, T., (2005). More Strawbale Building - A Complete Guide to Designing and Building with Straw. Canada: New Society, Gabriola Island, pp.1-2

Minke, G. (2006). Building with Earth, Birkhauser, Publishers for Architecture, Basel.

Morton, T. (2007). Towards the development of contemporary Earth Construction in the UK: drivers and benefits of Earth Masonry as a Sustainable Mainstream Construction Technique. In International Symposium on Earthen Structures, Indian Institute of Science, Bangalore (Vol. 2224).

Myhrman, M., Mac Donald, S. O., (1997). Build it with Bales: A Step-by-Step Guide to Straw Bale Construction. Version Two, Out on Bale, Tuscon, AZ, 15-118 
Niroumand, H., Zain, M. F. M., Jamil, M. (2013). Various types of earth buildings. Procedia-Social and Behavioral Sciences, 89, 226-230.

Reynolds, M. 1990, Earthship Volume 1: How to Build Your Own. Solar Survival Press, Taos, New Mexico. Reynolds, M. 2000, Comfort In Any Climate. Solar Survival Press, Taos, New Mexico.

Sargentis, G. F., Kapsalis, V. C., Symeonidis, N. (2009). Earth building. Models, technical aspects, tests and environmental evaluation. In11th International Conference on Environmental Science and Technology Chania.

Walker, P., Keable, R., Martin, J., Maniatidis, V. (2005). Rammed earth: design and construction guidelines. Watford: BRE Bookshop.

Zhao, Z., Lu, Q., Jiang, X. (2015). An Energy Efficient Building System Using Natural ResourcesSuperadobe System Research. Procedia Engineering, 121, 1179-1185. 